\title{
KONDISI KUALITAS AIR HABITAT PESUT MAHAKAM (Orcaella brevirostris) DI WILAYAH DAERAH ALIRAN SUNGAI MAHAKAM, KALIMANTAN TIMUR
}

\author{
Aisyah'), Dharmadi'), Syahroma Husni Nasution'2), Dian Oktaviani'1), dan Dede Irving Hartoto') \\ 1) Peneliti pada Pusat Riset Perikanan Tangkap, Ancol-Jakarta Utara \\ 2) Peneliti pada Pusat Penelitian Limnologi-Lembaga Ilmu Pengetahuan Indonesia, Cibinong-Jawa Barat \\ Teregristrasi I tanggal: 12 Maret 2007; Diterima setelah perbaikan tanggal: 17 Maret 2008; \\ Disetujui terbit tanggal 20 Maret 2008
}

ABSTRAK

Sungai Mahakam merupakan sungai terpanjang dan terbesar di Propinsi Kalimantan Timur dan menjadi habitat dari pesut (Orcaella brevirostris). Kondisi habitat diduga berkaitan dengan kecendrungan menurunnya populasi pesut, untuk itu perlu dilakukan penelitian mengenai kondisi kualitas air habitat pesut. Penelitian dilakukan di wilayah daerah aliran Sungai Mahakam, Kalimantan Timur pada bulan Oktober 2004 dan Oktober 2005 yang mewakili musim kemarau (air rendah) serta bulan Desember 2005 yang mewakili musim hujan (air tinggi) di 5 stasiun. Parameter kualitas air terdiri atas parameter fisika dan kimia yang dikompositkan dari lapisan bawah sampai dengan permukaan menggunakan water quality checker Horiba U-10. Secara umum, tipe perairan tergolong eutrofik dengan kondisi kualitas air yang tergolong aman diperuntukkan bagi habitat pesut.

\section{KATAKUNCI: $\quad$ kualitas air, eutrofik, pesut, Orcaella brevirostris}

ABSTRACT: $\quad$ Water quality condition of Irrawady Dolphin (Orcaella brevirostris) habitat in Mahakam River reguin of East Kalimantan. By: Aisyah, Dharmadi, Syahroma Husni Nasution, Dian Oktaviani, and Dede Irving Hartoto

\begin{abstract}
Mahakam River is one of the longest and biggest river in East Kalimantan Province and becoming the habitat for Irrawady Dolphin, locally refers as Pesut (Orcaella brevirostris). It is important to understand about the condition of water quality that support the pesut habitat which has degradated. The sampling was conducted three times in Oktober 2004 and, October and December 2005 when it represented the low water and the high water condition's respectivelly. At each sampling station physical and chemical parameters were analysed. Water samples were taken from each station as a composit samples taken from the bottom and surface layers and analysis was conducted using water quality checker Horiba U-10. In general, the locations of sampling station were classified as eutrophic water with most of the water quality would still meet the requirement for Irrawady Dolphin habitat.
\end{abstract}

KEYWORDS: $\quad$ water quality, eutrophic, Irrawady Dolphin, Orcaella brevirostris

\section{PENDAHULUAN}

Populasi pesut di daerah aliran Sungai Mahakam Propinsi Kalimantan Timur pada saat ini diperkirakan sekitar 34 sampai dengan 55 ekor (Kreb \& Budiono, 2004). Sekitar tahun 1970-an dikatakan antara 100 sampai dengan 150 ekor yang tersebar di Danau Melintang, Danau Semayang, Sungai Pela, dan sebagian Sungai Mahakam (Ridgway \& Harrison, 1989; van Hoeve, 1996). Kenyataan ini menunjukkan bahwa telah terjadi penurunan jumlah populasi sekitar $30 \%$ dalam jangka waktu sekitar 25 tahun.

Penurunan populasi pesut disebabkan oleh ancaman dan gangguan yang meliputi penangkapan ikan secara besar-besaran (over fishing), teknik penangkapan ikan yang kurang efektif dan mengganggu kehidupan pesut dan habitatnya (terperangkap dalam jaring rengge, penggunaan racun, dan listrik dalam menangkap ikan), perusakan hutan (deforestation), lalu lintas air, dan polusi suara dari speed boat serta penangkapan pesut untuk penangkaran (Anonimus, 1999).

Kekhawatiran yang terkait dengan keberadaan populasi pesut yang semakin berkurang tergambar dengan naiknya status pesut dalam daftar Convention on International Trade in Endangered Species of Wild Fauna and Flora dari Lampiran II menjadi Lampiran I (Samedi, 2004). Pesut juga masuk ke dalam Redlist IUCN dan tergolong dalam critically endangered dengan status tambahan data deficient (Redlist, 2004). Di Indonesia sendiri perlindungan terhadap pesut didasarkan pada Surat Keputusan Menteri Pertanian No.35/Kpts/Um/l/1975 dan UU No.5/1990 dipertegas oleh Keputusan Menteri Kehutanan No.301/Kpts-II/ 1991 dan Surat Keputusan Menteri Kehutanan No.882/ Kpts-II/1992. 
Terkait dengan penurunan populasi pesut, faktor kualitas air dianggap penting untuk diketahui, mengingat keterkaitan terhadap keberadaan pesut di lingkungan habitat tersebut. Habitat merupakan tempat untuk mencari makan, tempat berlindung, tempat bermain, dan berkembang biak. Menurut Alikodra (1980), habitat merupakan tempat-tempat yang berfungsi untuk mencari makan, untuk berlindung, bermain dan berkembang biak yang membentuk satu kesatuan. Sedangkan menurut Smiet (1986) dalam Priyono, A. (1993), habitat merupakan tempat di mana organisme dapat ditemui, yaitu suatu lahan tertentu yang ditempati organisme atau komunitas.

Penelitian ini bertujuan untuk mengetahui kondisi kualitas air di lokasi penelitian yang merupakan habitat pesut, sehingga dapat diketahui status perairan pada saat ini dan keterkaitan dengan keberadaan pesut.

\section{BAHAN DAN METODE}

\section{Lokasi Pengambilan Contoh dan Metode Analisis}

Pengukuran dan pengambilan contoh air dikelompokkan pada wilayah Sungai Mahakam yang meliputi Sungai Pela, Tanjung Lilin (outlet Danau Semayang), Tanjung Halat, dan wilayah danau yang meliputi Danau Semayang serta Danau Melintang (Muara Rebak Rinding yang juga merupakan inlet Danau Melintang) (Gambar 1). Pengamatan contoh pada masing-masing stasiun air dilakukan 3 kali yaitu bulan Oktober 2004 dan Oktober 2005 yang mewakili

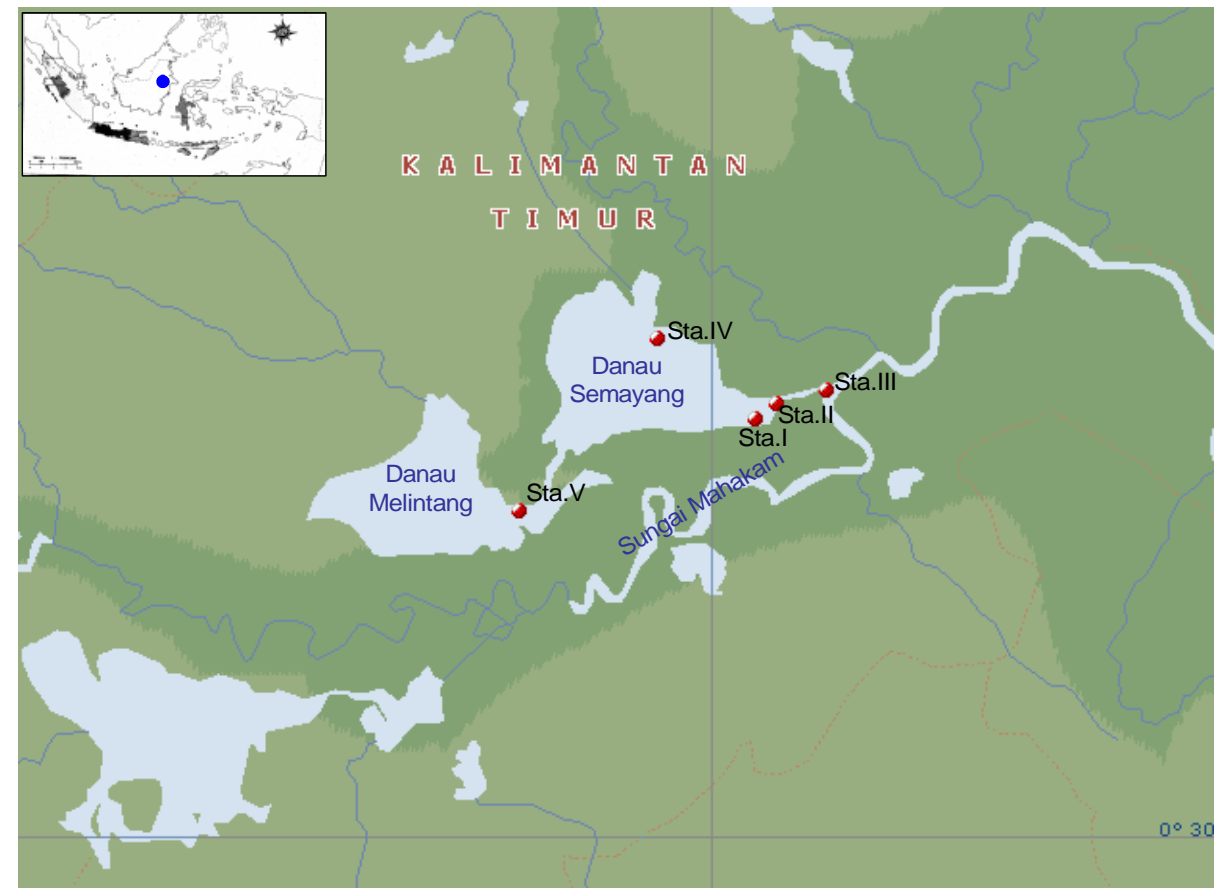

Gambar 1. Stasiun penelitian untuk pengambilan contoh air. Figure 1. Location of sampling station.

Keterangan/Remarks: Stasiun I = Tanjung Halat; Stasiun II = Tanjung Lilin; Stasiun III = Muara Sungai Pela; Stasiun IV = Danau Semayang; Stasiun V = Danau Melintang

air rendah dan bulan Desember 2005 yang mewakili air tinggi.

Parameter fisika kualitas air yang dicatat meliputi suhu, $\mathrm{pH}$, konduktivitas, turbiditas, dan oksigen terlarut (DO) yang diukur secara acak 3 kali menggunakan water quality checker, Horiba tipe U10). Untuk menganalisis kandungan $\mathrm{N}$-nitrit $\left(\mathrm{N}-\mathrm{NO}_{2}\right)$, $\mathrm{N}$-nitrat $\left(\mathrm{N}-\mathrm{NO}_{3}\right), \mathrm{N}$-amonia $\left(\mathrm{N}-\mathrm{NH}_{4}\right)$, Total-nitrogen (TN), P-fosfat (P-PO $)$, dan Total-posfor (TP) contoh air dikompositkan dari lapisan bawah sampai dengan permukaan. Semua contoh dipersiapkan dan dianalisis menggunakan metode seperti pada Tabel 1. yang mengacu pada standard methods for the examination of water and wastewater (APHA-AWWAWEF, 1998).

\section{HASIL DAN BAHASAN}

Perubahan kualitas air dipengaruhi oleh perubahan muka air. Dalam proses tersebut juga akan terjadi proses pelarutan mineral-mineral dari tanah yang sebelumnya kering, diikuti oleh proses pembusukan 
tumbuh-tumbuhan yang hidup di lahan surutan tersebut. Beberapa parameter kualitas air seperti

oksigen terlarut, $\mathrm{pH}$, kekeruhan, konduktivitas, total nitrogen, dan total fosfat menunjukkan perubahan sebagai akibat dari perubahan muka air tersebut (Tabel 2, 3, dan 4).

Tabel 1. Metode analisis parameter kualitas air

Tabel 1. Analysis methods of water quality parameters

\begin{tabular}{cll}
\hline No. & \multicolumn{1}{c}{ Parameter/Parameter } & \multicolumn{1}{c}{ Metode/Method } \\
\hline 1 & N-nitrit & Sulfanilamid, spektrofotometer \\
2 & N-nitrat & Brucin, spektrofotometer \\
3 & N-amonia & Phenate, spektrofotometer \\
4 & T-nitrogen & Brucin, dioksidasi dengan $\mathrm{K}_{2} \mathrm{~S}_{2} \mathrm{O}_{8}$, spektrofotometer \\
5 & P-fosfat & Asam askorbat \\
6 & T-fosfor & Dioksidasi dengan $\mathrm{H}_{2} \mathrm{SO}_{4}$, spektrofotometri \\
\hline
\end{tabular}

Tabel2. Deskripsi stasiun penelitian

Table 2. Description of sampling station

\begin{tabular}{|c|c|c|c|}
\hline \multirow{2}{*}{$\begin{array}{l}\text { Stasiun/ } \\
\text { Station }\end{array}$} & \multirow{2}{*}{$\begin{array}{l}\text { Lokasi pengambilan contoh/ } \\
\text { Location of sampling station }\end{array}$} & \multicolumn{2}{|c|}{ Koordinat/Coordinate } \\
\hline & & Lintang/Latitude & Bujur/Longitude \\
\hline 1 & Tanjung Halat & S 00¹5'10,3” & E 116³1’01,3”' \\
\hline II & Tanjung Lilin & $S 00^{\circ} 14^{\prime} 43,6^{\prime \prime}$ & E 116 32 '12,0" \\
\hline III & Sungai Pela & S $00^{\circ} 14^{\prime} 09,9^{\prime \prime}$ & E 116 $33^{\prime} 55,2^{\prime \prime}$ \\
\hline IV & Danau Semayang & S 00¹2'56,3”' & E 116²8'32,1" \\
\hline $\mathrm{V}$ & Danau Melintang & S 00¹8'34,9"' & E 116²3'47,2" \\
\hline
\end{tabular}




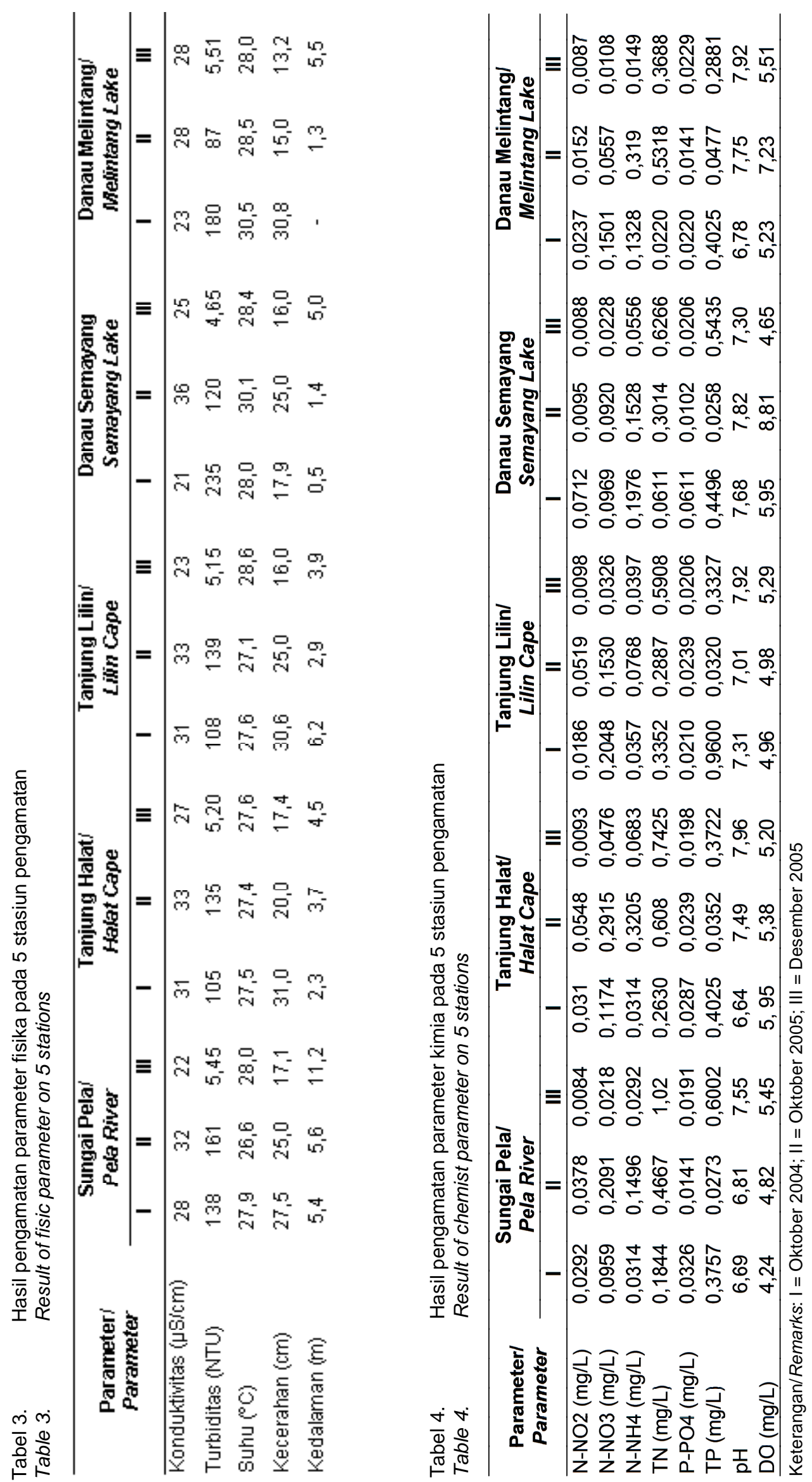


Nilai konduktivitas di setiap stasiun baik pada saat air tinggi maupun pada saat air rendah berada di kisaran nilai 21 sampai dengan $36 \mu \mathrm{S} / \mathrm{cm}$. Nilai konduktivitas perairan pada saat air rendah cenderung tinggi, hal ini tidak sesuai dengan yang dikatakan Welcomme (1979) dalam Lukman (1998), khususnya pada danau-danau paparan banjir yang menunjukkan tingkat konduktivitas minimum selama musim kering (mirip periode penyurutan) dan maksimum selama fase pra penggenangan. Kenyataan ini diduga pada saat air rendah tepat bulan Oktober merupakan awal musim penghujan atau dapat dikatakan sebagai banjiran awal di mana terjadi pelarutan garam-garam yang tersimpan pada tanah kering yang mulai terendam sehingga terjadi pengkayaan nutrien dalam perairan tersebut. Jenis tanah di daerah ini didominasi oleh tanah organosol di bagian berawa, tanah podsolik di bagian punggung daratan dan sedikit jalur tanah aluvial di kiri kanan sungai (Priyono, 1993). Jenis tanah organosol berasal dari bahan induk organik seperti dari hutan rawa atau rumput rawa. Pada umumnya jenis tanah-tanah tersebut sangat peka terhadap erosi.

Tingkat kekeruhan pada saat air tinggi mengalami penurunan di semua stasiun yang diamati. Terlihat nilai turbiditas di seluruh stasiun pada saat air rendah cenderung lebih tinggi, hal ini menunjukkan bahwa di setiap stasiun penelitian telah terjadi laju erosi yang tinggi akibat aktivitas manusia yang mengeksploitasi hutan dan pembukaan lahan pertanian di sekitar daerah aliran sungai yang diduga mengakibatkan terkikis lapisan permukaan tanah (Anonimus, 1999). Nilai turbiditas tertinggi terjadi di Danau Semayang saat air rendah. Hal ini, diduga karena terjadi pengadukan yang intensif sampai dengan ke dasar perairan akibat dangkal danau.

Turbiditas suatu perairan akan mempengaruhi penetrasi cahaya atau sinar matahari yang masuk ke dalam perairan, sehingga akan mempengaruhi proses fotosintesis. Di samping itu, hewan akuatik seperti ikan akan sangat dipengaruhi oleh turbiditas. Turbiditas atau kekeruhan yang disebabkan oleh lumpur dan partikel yang dapat mengendap sering menjadi faktor pembatas pertumbuhan ikan (Odum, 1996).

Suhu air di 5 stasiun berkisar antara 26,6 sampai dengan $30,5^{\circ} \mathrm{C}$. Boyd (1990) mengatakan bahwa suhu optimum untuk pertumbuhan ikan berkisar antara 25 sampai dengan $32^{\circ} \mathrm{C}$. Suhu air baik pada saat air tinggi maupun air rendah tidak menunjukkan fluktuasi yang besar. Hal ini, diperkirakan terjadi karena percampuran air yang intensif di sungai dan danau di lokasi penelitian. Pada umumnya suhu air sungai jarang menunjukkan perubahan, karena ada percampuran yang terus berlangsung dan ada turbulensi sejalan dengan aliran air (Lukman, 1998).

Nilai oksigen terlarut (DO) baik pada saat air rendah maupun saat air tinggi berkisar antara 4,24 sampai dengan $8,81 \mathrm{mg}$ per L. Pada saat air tinggi kadar oksigen terlarut cenderung menurun daripada saat air rendah. Fenomena ini terjadi dan mencirikan suatu siklus yang umum di dalam sistem paparan banjir seperti yang dikatakan oleh Welcomme (1979) dalam Lukman (1998). Dikatakan bahwa sejalan dengan air banjiran menginvasi wilayah paparan banjir, peningkatan kadar oksigen terlarut akan terjadi, tetapi sejalan dengan proses pembusukan vegetasi tenggelam mengakibatkan penurunan kadar oksigen terlarut.

Nilai tertinggi oksigen terlarut tertinggi ditemukan di Danau Semayang yaitu 8,81 mg per L. Hal ini, diduga akibat proses fotosintesis fitoplankton serta terdapat banyak tumbuhan air eceng gondok (Eichornia crassipes) di perairan tersebut. Nasution et al. (2000) mengatakan pada perairan yang mengalir, perairan yang terdapat tanaman air, dan permukaan danau pada umumnya memiliki kandungan oksigen yang tinggi, berkisar antara 6 sampai dengan $8 \mathrm{mg}$ per I. Peraturan Pemerintah No.82 tahun 2001 tentang pengelolaan kualitas air dan pengendalian pencemaran air, menetapkan bahwa kandungan oksigen terlarut yang baik untuk perairan kelas III yaitu dengan batas minimum $3 \mathrm{mg}$ per L, air yang peruntukannya dapat digunakan untuk pembudidayaan ikan air tawar, peternakkan, air untuk mengairi pertanaman, dan atau peruntukan lain yang mempersyaratkan air yang sama dengan kegunaan tersebut. Dari hasil penelitian ini terlihat bahwa secara umum kandungan oksigen terlarut cukup tinggi sehingga mampu mendukung kehidupan ikan di perairan tersebut.

Nilai $\mathrm{pH}$ rata-rata perairan pada musim air rendah masing-masing berkisar 6,64 sampai dengan 7,82. Sedangkan pada musim air tinggi berkisar antara 7,55 sampai dengan 7,96 . Nilai pH cenderung meningkat pada saat air tinggi, namun tidak demikian dengan Danau Semayang, di mana pada saat air tinggi justru nilai $\mathrm{pH}$ menurun. Keadaan ini sejalan dengan penurunan oksigen terlarut. Penurunan $\mathrm{pH}$ tersebut diduga akibat meningkatnya limpasan air dari Sungai Mahakam sehingga menetralisir aliran air dari perairan-perairan rawa (hutan rawa air tawar) yang memiliki pH 4,5, yang tersebar baik di sekitar danau maupun sepanjang tepi aliran Danau Semayang. Berdasarkan pada Peraturan Pemerintah No.82 tahun 
2001 bahwa kadar maksimum pH yang diizinkan untuk perikanan 6 sampai dengan 9 . Hal ini, menunjukkan bahwa $\mathrm{pH}$ air dapat mendukung kehidupan yang ada.

Konsentrasi parameter kimia di 5 stasiun dapat dilihat pada Tabel 4. Unsur $\mathrm{N}$ dan $\mathrm{P}$ sangat terkait dengan proses penyuburan perairan. Tinggi unsur $\mathrm{N}$ dan $P$ yang masuk ke dalam perairan secara terusmenerus akan berakibat terjadi gangguan terhadap ekosistem seperti blooming plankton. Parameter kimia yang berkaitan dengan proses dekomposisi menunjukkan bahwa nilai relatif stabil terkecuali pada saat air tinggi. Kisaran nilai total $\mathrm{N}$ baik pada saat air tinggi maupun saat air rendah 0,0611 sampai dengan $1,02 \mathrm{mg}$ per L. Total N di Sungai Pela mencapai nilai tertinggi $1,02 \mathrm{mg}$ per $\mathrm{L}$ pada saat air tinggi. Karena Sungai Pela merupakan outlet Danau Semayang, maka tinggi kadar total $\mathrm{N}$ diduga oleh akumulasi serasah tumbuhan dari Danau Semayang sehingga proses perombakan yang terjadi lebih intensif. Dari nilai total $\mathrm{N}$ di semua stasiun secara relatif menunjukkan bahwa perairan dapat dikategorikan sebagai perairan eutrofik. Berdasarkan pada Vollenweider \& Karekes (1980) dalam Lukman (1998), dikatakan bahwa perairan yang memiliki kadar Total $\mathrm{N}$ berkisar antara 0,393 sampai dengan $6,1 \mathrm{mg}$ per $\mathrm{L}$ diklasifikasikan sebagai perairan eutrofik.

Tinggi kadar total $\mathrm{N}$ pada saat air tinggi dibandingkan dengan air rendah, merupakan suatu proses yang berkaitan di dalam sistem paparan banjir. Pada saat air rendah tumbuhan air dan tumbuhan terestrial yang ada pada surutan danau mulai terendam kembali, sehingga mempercepat proses perombakan yang melibatkan pelarutan komponen nitrogen dari tumbuhan dan tanah-tanah yang sebelumnya kering. Sedangkan pada periode air tinggi, walaupun komponen nitrogen dimanfaatkan secara intensif oleh fitoplankton dan tumbuhan air, namun pelarutan tidak sebesar pada saat air rendah, sehingga kadar Total $\mathrm{N}$ terutama di danau sangat rendah, hal ini terbukti dengan nilai total $\mathrm{N}$ di Danau Semayang dan Danau Melintang pada saat air rendah (bulan Oktober 2004) relatif lebih kecil dibanding dengan stasiun lain.

Nilai total P di 5 stasiun baik pada saat air tinggi maupun saat air rendah berkisar antara 0,0258 sampai dengan $0,9600 \mathrm{mg}$ per $\mathrm{L}$. Nilai total $P$ tertinggi ditemukan di Sungai Tanjung Lilin 0,9600 mg per $\mathrm{L}$ pada saat air rendah. Hal ini, diduga karena kurang intensif peran fitoplankton oleh karena jumlah tidak sebanding dengan total $\mathrm{P}$ yang ada di perairan tersebut. Nasution et al. (2005) mengatakan bahwa kelimpahan fitoplankton di Sungai Pela, Tanjung Halat, dan Tanjung Lilin lebih rendah dibandingkan di Danau Semayang dan Melintang. Berdasarkan pada Peraturan Pemerintah No.82 tahun 2001 nilai total fosfat sebagai $P$ adalah 1 untuk perairan yang tergolong kelas III. Ini berarti nilai total P di 5 stasiun air yang peruntukkan dapat digunakan untuk pembudidayaan ikan air tawar, peternakkan, air untuk mengairi pertanaman, dan atau peruntukan lain yang mempersyaratkan air yang sama dengan kegunaan tersebut.

\section{KESIMPULAN}

Kondisi kualitas air di Sungai Pela, Tanjung Lilin, Tanjung Halat, Danau Semayang, serta Danau Melintang menunjukkan bahwa perairan tergolong baik untuk habitat pesut. Naik permukaan air menimbulkan peningkatan total $\mathrm{N}$ dan $\mathrm{P}$ yang mencirikan bahwa perairan di 5 stasiun tergolong eutrofik; namun menyebabkan penurunan konduktivitas, kekeruhan, dan kadar oksigen terlarut.

\section{PERSANTUNAN}

Kegiatan dari hasil riset inventarisasi mamalia air (pesut), penyu, dan labi-labi, T.A. 2006, di Pusat Riset Perikanan Tangkap, Ancol-Jakarta.

\section{DAFTAR PUSTAKA}

Alikodra, H. S. 1980. Dasar-dasar pembinaan marga satwa. Fakultas Kehutanan. Institut Pertanian Bogor. Bogor.

Anonimus. 1999. Laporan penelitian pesut di perairan Sungai Mahakam dan danau-danau di sekitarnya (pada musim kemarau). Departemen Kehutanan dan Perkebunan. Balai Konservasi Sumber Daya Alam Kalimantan Timur.

APHA-AWWA-WEF. 1998. Standar methods for the examination of water and wastewater. $20^{\text {th }}$ Edition. Washington.

Boyd, C. E. 1990. Water quality in ponds for aquaculture. Birmingham Publishing Co. Auburn. Alabama. USA.

Kreb, D \& Budiono. 2004. Conservation management of small core areas: Key to survival of a critically endangered population of riverine Irrawaddy dolphins in Borneo. Conservation and Social Ecology of Freshwater and Coastal Irrawaddy Dolphins in Indonesia. Noordoostpolder. Febodruk B. V. Enschede. Hal.81-104. 
Lukman. 1998. Kualitas air Danau Semayang pada periode pra penyurutan dan pra penggenangan. Limnotek. Perairan Darat Tropis di Indonesia. V (1).

Nasution, S., Hartoto, Dharmadi, \& Oktaviani, D. 2005. Struktur komunitas dan kelimpahan fitoplankton di lingkungan habitat pesut Mahakam. Laporan Hasil Penelitian. 2005.

Odum, E. P. 1996. Dasar-dasar ekologi. Diterjemahkan oleh T. Samingan. Edisi ke-3. Gajah Mada University Press. Yogyakarta.

Priyono, A. 1993. Telaah habitat pesut (Orcaella brevirostris) di Danau Semayang dan sekitarnya.
Tesis. Fakultas pascasarjana. Institut Pertanian Bogor. Bogor.

Ridgway, S. H. \& Harisson S. R. 1989. River dolpin and the large toothed whales. Handbook of Marine Mammals. Vol.4. London. Academic Press.

Samedi. 2004. Laporan convention on international trade in endangered species of wild fauna and flora $13^{\text {th }}$ meeting of the conference of the parties. Bangkok. 2-14 Oktober 2004. www.dephut.go.id Rabu 28 Juni 2006.

Van Hoeve, W. 2003. Ensiklopedia Indonesia seri fauna. Mamalia. Jilid 1 Jakarta. P.T. Ichtiar Baru Van Hoeve. 